\title{
Predatory Mite, Neoseiulus californicus (McGregor) (Arachnida: Acari: Phytoseiidae) ${ }^{1}$
}

\author{
Elena M. Rhodes and Oscar E. Liburd²
}

\section{Introduction}

The predatory mite Neoseiulus californicus (McGregor) has characteristics of both type II specialist predatory mites and type III generalist predatory mites. $N$. californicus prefers Tetranychid mites as food, but will also consume other mite species, small insects, such as thrips, and even pollen when the primary prey is unavailable.

$N$. californicus is often used to control the twospotted spider mite, Tetranychus urticae Koch, and other phytophagous mites on various crops in temperate and subtropical regions around the world.

\section{Synonymy}

$N$. californicus has a very complex taxonomic history. It was first described by McGregor in 1954 from lemon in California as Typhlodromus californicus. After 1954, it was moved to the genus Amblyseius and later to the genus Neoseiulus or Cydnodromus, and now Neoseiulus chilenensis (Dosse) is considered a synonym of $N$. californicus.

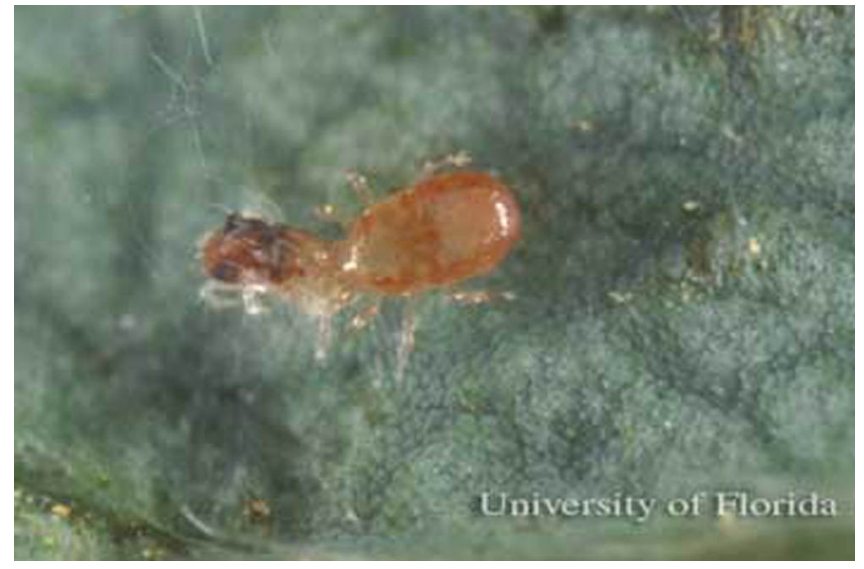

Figure 1. Adult Neoseiulus californicus (McGregor) feeding on a twospotted spider mite, Tetranychus urticae Koch. Credits: Lyle Buss, University of Florida

\section{Distribution}

Natural populations of $N$. californicus, are found in Argentina, California, Chile, Florida, Japan, South Africa, Texas, parts of southern Europe, and all along the border of the Mediterranean Sea. N. californicus has been found on many crops including avocado, citrus and other fruit trees. They are also found on cassava, corn, grapes, strawberries, and several vegetable crops and ornamental plants. They prefer warm $10-33^{\circ} \mathrm{C}\left(50-91^{\circ} \mathrm{F}\right)$ temperatures, but they

1. This document is EENY-359, one of a series of Featured Creatures from the Entomology and Nematology Department, Florida Cooperative Extension Service, Institute of Food and Agricultural Sciences, University of Florida. Published: November 2005. This document is also available on Featured Creatures Website at http://creatures.ifas.ufl.edu. Please visit the EDIS Website at http://edis.ifas.ufl.edu.

2. Elena M. Rhodes and Oscar E. Liburd, Department of Entomology and Nematology, University of Florida, Gainesville, FL.

The Institute of Food and Agricultural Sciences (IFAS) is an Equal Opportunity Institution authorized to provide research, educational information and other services only to individuals and institutions that function with non-discrimination with respect to race, creed, color, religion, age, disability, sex, sexual orientation, marital status, national origin, political opinions or affiliations. U.S. Department of Agriculture, Cooperative Extension Service, University of Florida, IFAS, Florida A. \& M. University Cooperative Extension Program, and Boards of County Commissioners Cooperating. Larry Arrington, Dean 
can tolerate much colder temperatures for short periods of time. For example, they can survive the winters in north Florida where temperatures can fall below freezing at night. They can tolerate a wide range of humidity ( $40-80 \%$ relative humidity), but prefer humidity at the upper end of this range.

\section{Description}

$N$. californicus eggs are football shaped, approximately $0.04 \mathrm{~mm}(0.00016 \mathrm{in})$ in length, and are pale whitish in color. Larvae have only six legs and are translucent in color. Both nymphal stages, the protonymph and the deutonymph, resemble the adults except that they are smaller and cannot reproduce. Adult females are approximately $0.1 \mathrm{~mm}$ (0.00039 in) in length and oval in shape. Males are slightly smaller than females. Both males and females are translucent and can be pale orange, peach, or pink in color.

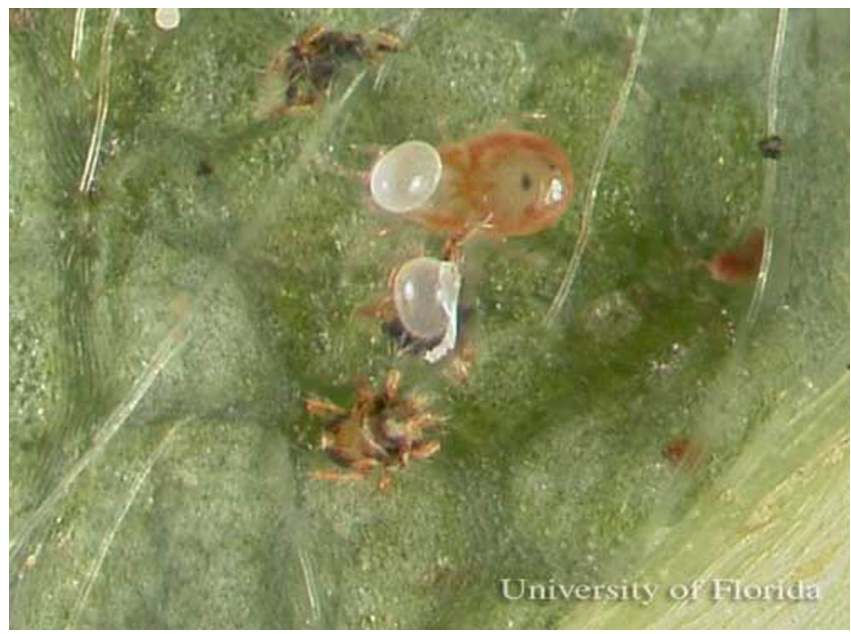

Figure 2. Two eggs of Neoseiulus californicus (McGregor) attached to leaf hairs on a strawberry leaf. Credits: Elena M. Rhodes, University of Florida

\section{Life Cycle}

$N$. californicus females can lay up to four eggs a day. However, two eggs per day is the average. Eggs take from 1.5 to 4.0 days to hatch depending on the temperature. Eggs hatch into six-legged larvae, which can progress to the protonymphal stage without feeding. The larval stage can last from 0.5 to 1.0 day. $N$. californicus then passes through two nymphal stages: protonymph and deutonymph. Both stages (protonymph and deutonymph) are active feeders. Each nymphal stage can last from 1.0 to 3.0 days. Total developmental time can be as short as 4.0 days

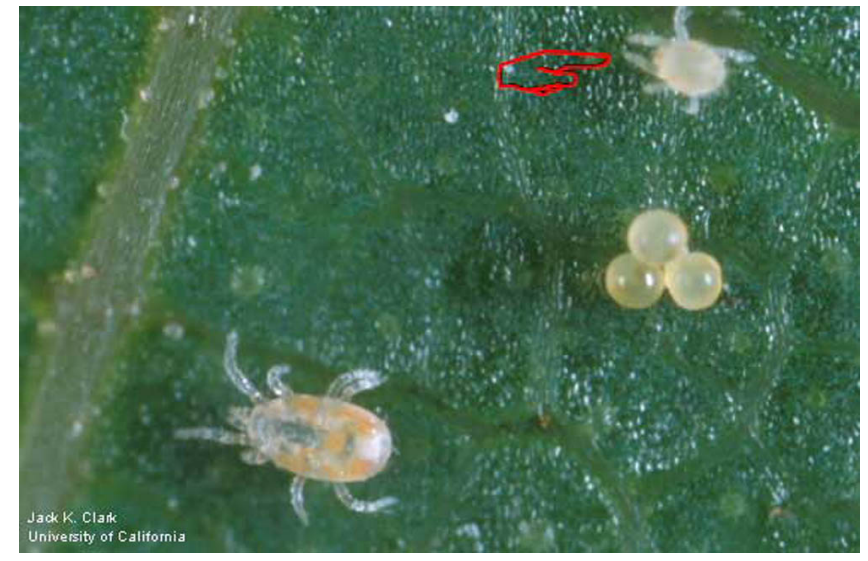

Figure 3. Dorsal view of a Neoseiulus californicus (McGregor) larva indicated by pointer. An adult $N$. californicus and a cluster of spider mite eggs are shown for size comparison. Credits: Jack Kelly Clark, University of California

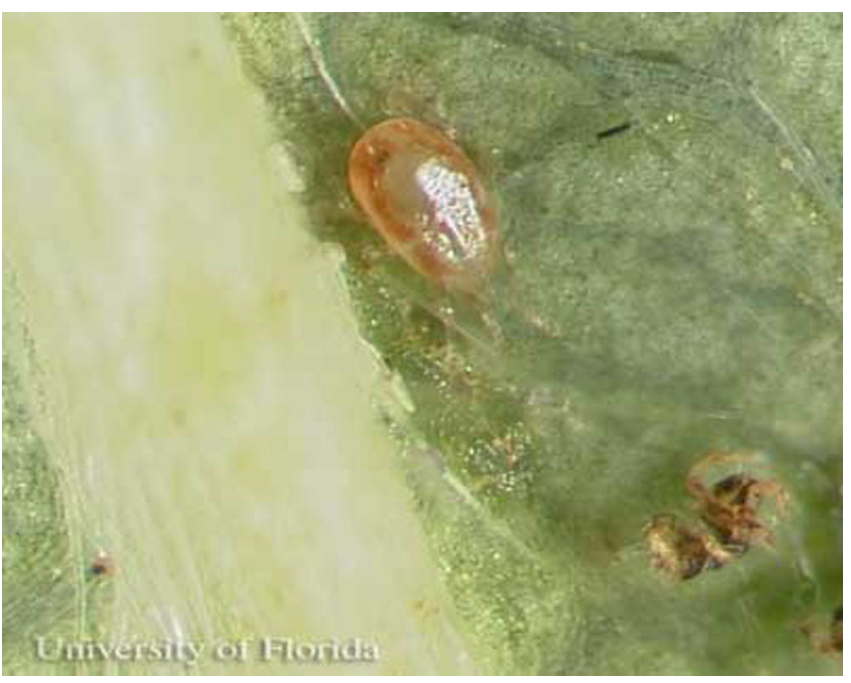

Figure 4. Dorsal view of adult female Neoseiulus californicus (McGregor) on a strawberry leaf. Credits: Elena M. Rhodes, University of Florida

or as long as 12.0 days depending on the temperature. $N$. californicus develops more quickly at higher temperatures. Adults live for approximately 20 days.

$N$. californicus develops faster when consuming the twospotted spider mite, Tetranychus urticae Kotch, than when consuming other prey sources. However, it will also successfully develop and reproduce when consuming other mite species including: Aculus schlenchtendali (Nalepa), Oligonychus pratensis (Banks), O. perseae Tuttle, $O$. ilicis (McGregor), Panonychus ulmi (Koch), Phytonemus pallidus (Banks), Polyphagotarsonemus (Stenotarsonemus) latus Banks (the broad mite), and Phytonemus pallidus L. (the cyclamen mite). Many 
of these mites are crop pests. It can also survive and reproduce by consuming thrips and other small insects, but reproduction is very low. $N$. californicus can even survive for a short period of time by consuming only pollen.

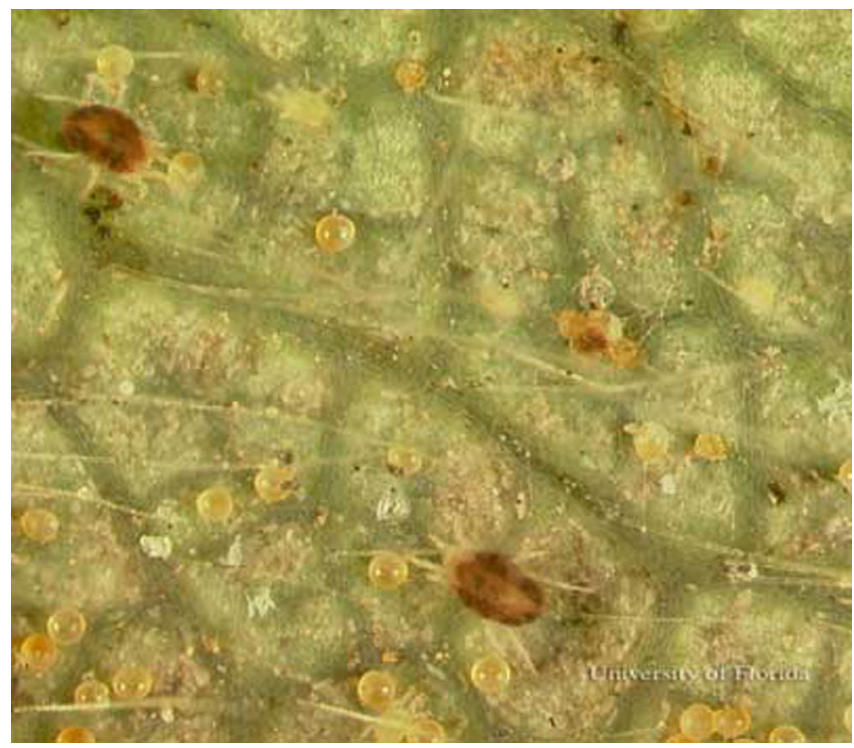

Figure 5. A strawberry leaf infested with twospotted spider mite, Tetranychus urticae Koch, adults and their eggs. Credits: Lyle Buss, University of Florida

\section{Economic Importance}

N. californicus is used commercially around the world to control the twospotted spider mite and several other economically important mites on avocado, citrus, dwarf hops, grapes, raspberries, roses and other ornamentals, strawberries, and several vegetable crops. It has been shown to effectively control the twospotted spider mite and P. pallidus on strawberries in glasshouses in the UK and in greenhouses in Argentina. In the U.S., N. californicus has been used successfully to control twospotted spider mites on field grown strawberries in southern California and Florida. N. californicus has also been used to control the twospotted spider mite on dwarf hops and to control $O$. perseae on avocado, to mention a few examples.

The recommended release rate depends on pest species, pest density, and crop. In strawberry, a release rate of one female $N$. californicus per plant will maintain twospotted spider mite populations below the threshold level (5\% of leaves infested). $N$. californicus can also tolerate applications of certain miticides, which are sometimes used to knock down a high population of twospotted spider mites before predatory mites are released.

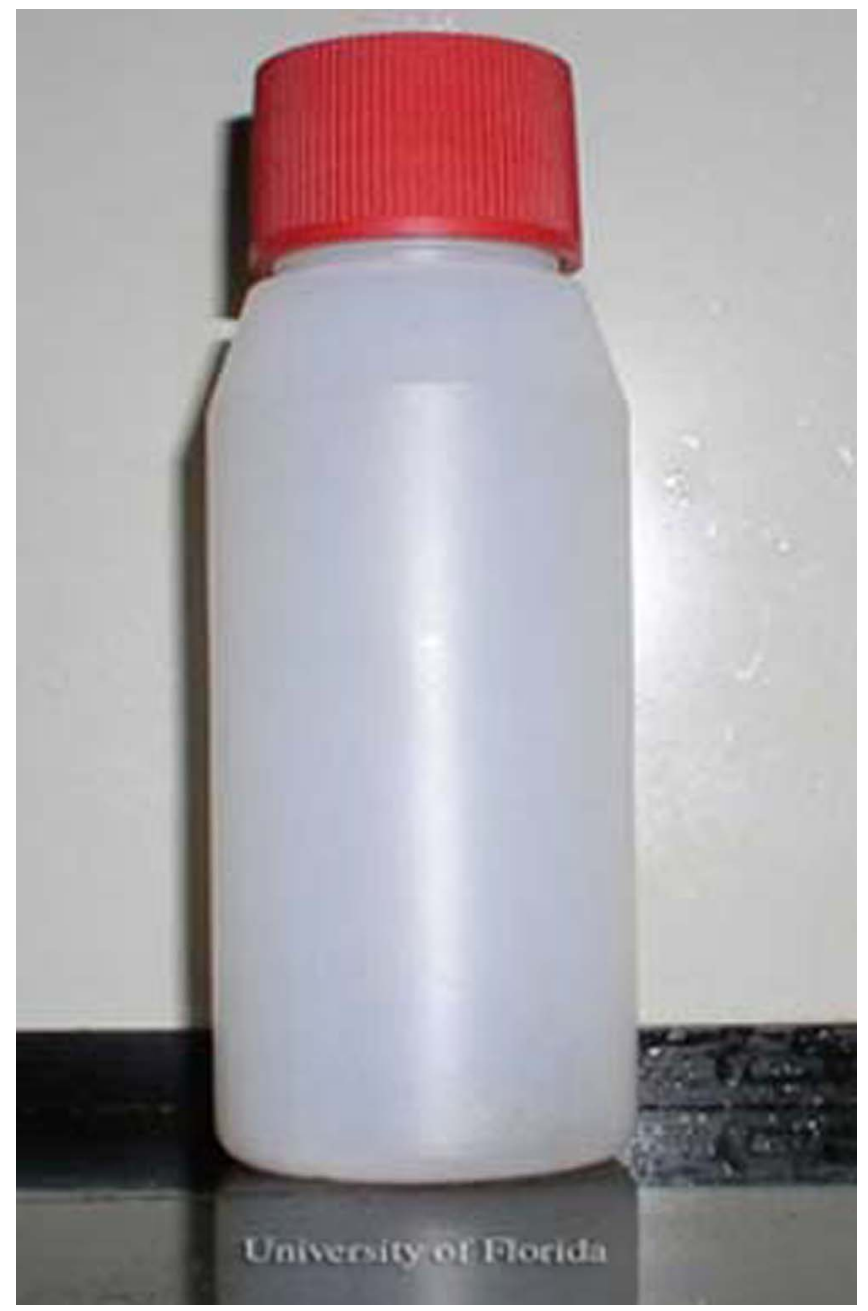

Figure 6. Commercial presentation of Neoseiulus californicus (McGregor) to be released on the field (courtesy of Koppert Biological Supply Co.). Credits: Elena Rhodes, University of Florida

\section{Selected References}

Barber A, Campbell CAM, Crane H, Lilley R, Tregidga E. 2003. Biocontrol of two-spotted spider mite Tetranychus urticae on dwarf hops by the phytoseiid mites Phytoseiulus persimilis and Neoseiulus californicus. Biocontrol Science and Technology 13: 275-284.,

Castagnoli M, Simoni S. 2003. Neoseiulus californicus (McGregor) (Acari Phytoseiidae): survey of biological and behavioral traits of a versatile predator. Redia 86: 153-164. 
Castagnoli M, Liguori M. 1991. Laboratory observations on duration of copulation and egg production of three Phytoseiid species fed on pollen. In: The Acari. Chapman and Hall, New York, NY. 231-239.

Croft BA, Monetti LN, Pratt PD. 1998. Comparative life histories and predation types: are Neoseiulus californicus and N. fallacies (Acari: Phytoseiidae) similar type II selective predators of spider mites. Environmental Entomology 27: 531-538.

Easterbrook MA, Fitzgerald JD, Solomon MG. 2001. Biological control of strawberry tarsonemid mite Phytonemus pallidus and two-spotted spider mite Tetranychus urticae on strawberry in the UK using species of Neoseiulus (Amblyseius) (Acari: Phytoseiidae). Experimental \& Applied Acarology 25: 25-36.

Gerson U, Smiley RL, Ochoa R. 2003. Mites (Acari) for pest control. Blackwell Publishing. Ames, IA. 556p.

Greco NM, Liljesthrom GG, Sanchez NE. 1999. Spatial distribution and coincidence of Neoseiulus californicus and Tetranychus urticae (Acari: Phytoseiidae, Tetranychidae) on strawberry. Experimental and Applied Acarology 23: 567-580.

Hoddle MS, Aponte O, Kerguelen V, Heraty J. 1999. Biological control of Oligonychus perseae (Acari: Tetranychidae) on avocado: evaluating release timing, recovery, and efficacy of six commercially available phytoseiids. International Journal of Acarology 25: 211-219.

Johnson WT, Lyon HH. 1991. Insects that feed on trees and shrubs. 2nd edition. Comstock Publishing Associates. 560p.

Krantz GW. 1978. A manual of acarology. Corvallis. Oregon State University, OR. 509p.

Liburd OE, Seferina GG, Dinkins DA. 2003. Suppression of twospotted spider mites. In: UF/IFAS Berry/Vegetable Times. November 2003.

Ma W-L, Laing JE. Biology, potential for increase and prey consumption of Amblyseius chilenesis (Dosse) (Acarina: Phytoseiidae). Entomophaga 18: 47-60.

McMurtry JA, Croft BA. 1997. Life-styles of Phytoseiid mites and their roles in biological control. Annual Review of Entomology 42: 291-321.

Oatman, ER, McMurtry JA, Gilstrap FE, Voth V. 1977. Effect of releases of Amblyseius californicus on the twospotted spider mite on strawberry in Southern California. Journal of Economic Entomology 70: 638-640.

Rondon SI, Price JF, Liburd OE, Francis R, Cantliff DJ. (2004). Neoseiulus californicus (McGregor). A predatory mite species for controlling twospotted spider mites in strawberries. EDIS. http://edis.ifas.ufl.edu/HS245 (31 October 2005). 